\title{
Contemporary Issues Surrounding an Impairment-Only Approach to Acquired Goodwill: A Selected Review
}

\author{
Jamaliah Abdul Majid ${ }^{1}$ \\ ${ }^{1}$ Tunku Puteri Intan Safinaz School of Accountancy, College of Business, Universiti Utara Malaysia, 06010 \\ Sintok, Kedah, Malaysia \\ Correspondence: Jamaliah Abdul Majid, Tunku Puteri Intan Safinaz School of Accountancy, College of Business, \\ Universiti Utara Malaysia, 06010 Sintok, Kedah, Malaysia.
}

Received: January 18, 2019

Accepted: March 20, 2019

Online Published: March 21, 2019

doi:10.5539/ibr.v12n4p90

URL: https://doi.org/10.5539/ibr.v12n4p90

\begin{abstract}
This paper presents a selected review of contemporary issues surrounding an impairment-only approach to accounting for acquired goodwill and addresses the question of whether an impairment-only approach has resulted in an improvement in an accounting for goodwill. The review is structured around three main themes: concerned raised by stakeholders regarding an impairment-only approach, causes of the debates on goodwill impairment, and proposed solutions offered by stakeholders. The contribution of this paper to the debate on an impairment-only approach to acquired goodwill is to demonstrate that even though an impairment-only approach has posed implementation, auditing and enforcement challenges, it has also encouraged standard-setters, regulators and firms worldwide to make concerted efforts in bringing in more clarity to the valuation of goodwill and its impairment test. The review ends by offering practical ways forward on an accounting for acquired goodwill.
\end{abstract}

Keywords: goodwill, goodwill impairment, delayed expected loss, impairment-only approach, IFRS 3, IAS 36

\section{Introduction}

In September 2008, Lehman Brothers Holding Inc., the fourth largest investment holding in the United States of America (US) collapsed, which pushed the then global financial crisis into a much deeper state (Glaum and Wyrwa, 2009; Jenkins, 2017). Many countries that were based on export-dependent economy were affected by the financial crisis. For example, Malaysia experienced the full impact of the financial crisis in the first quarter of 2009 (Central Bank of Malaysia, 2009). The collapsed of many large corporations during the global financial crisis triggered uncertainty about the value of assets available in the surviving firms (Gunn, 2017), especially when there are large differences between the book values and the market values of the assets. Consequently, a number of firms were questioned for not reducing the values of their assets, in particular, goodwill through its impairment losses (Laux and Leuz, 2010; Ramanna and Watts, 2012), or they were examined for taking excessive impairment losses of goodwill (Giner and Pardo, 2014). Hence, the global financial crisis has drawn renewal attention to the debate on goodwill and its impairment test (Glaum and Wyrwa, 2009; ESMA, 2013; ASBJ et al., 2014; Andre et al., 2016).

Regulatory bodies, such as the Securities and Exchange Commission in the US and the Financial Reporting Council in the United Kingdom (UK), increased their scrutinisation of firms' financial statements to see whether goodwill reported on the balance sheet is impaired (FRC, 2008; Sussholz, 2009). Likewise, the International Accounting Standards Board (IASB) conducted a Post-implementation Review of IFRS 3 Business Combinations in 2013 and added two projects concerning goodwill in their research agenda in 2015 (IASplus, Undated; IFRS Foundation, 2015; Johansson et al., 2016). Consequently, almost a decade after the global financial crisis, the debate and regulatory focus on goodwill and its impairment continue (Andre et al., 2016; Deller, 2017). In an effort to inform readers of the debate on goodwill and its impairment, this paper has two main objectives. First, the paper reviews contemporary issues surrounding an impairment-only approach to accounting for acquired goodwill. These issues cover the late recognition of an impairment loss of goodwill, which then cause goodwill to be overstated on the financial statements. Second, the paper addresses the question of whether an impairment-only approach has resulted in an improvement in an accounting for acquired goodwill. 


\section{Research Method}

This paper reviewed studies on an impairment-only approach to accounting for acquired goodwill published in the 2004-2018 period. 2004 represents the year when an impairment-only approach was first issued by the IASB under the new International Financial Reporting Standard (IFRS) 3 Business Combinations and the revised International Accounting Standard (IAS) 36 Impairment of Assets. These studies were identified through Google Scholar and selected journals using the following keywords: goodwill, impairment, IFRS 3, IAS 36, and amortization/amortisation. To ensure that the review presents an unbiased picture of the topic, this paper focuses on both the academic and practitioner journals. For the practitioner journals, there were 11 studies reviewed, mainly from audit firms and standard-setters.

For the academic journals, to select the highly relevant studies, following d'Arcy and Tarca (2018), the present study focuses on three journal rankings that are recognised at international levels, specifically, the United Kingdom (UK) Association of Business School Academic Journal Guide, the Australian Business Dean Council (ABDC) ranking and the German VHB-JOURQUAL 3 ranking by the German Academic Association for Business School. For the last two ranking, this paper selected journals that are ranked at least C. From these selection procedures, 20 empirical studies were selected of which 19 studies were published in accounting journals while one study was published in a business journal. The majority of the accounting journals were from journals that are ranked A* (3 studies), A (6 studies) and B (6 studies) by the ABDC ranking. This suggests that the contemporary issue of an impairment-only approach to acquired goodwill is an important topic that motivates high-quality academic research.

Overall, this paper reviewed 31 studies of which 20 were from academic journals and eleven were from practitioner journals. The review of an impairment-only approach to accounting for acquired goodwill is structured around three main themes. These are: concerned raised by stakeholders regarding an impairment-only approach, causes of the debates, and proposed solutions offered by stakeholders. The review also offers practical ways forward on an accounting for acquired goodwill.

\section{Findings and Discussion}

\subsection{Concerns Raised by Stakeholders Regarding an Impairment-Only Approach}

From the review of literature, two interrelated issues seem to dominate the discussion on an impairment-only approach to acquired goodwill. First, the impairment losses of goodwill have not been recognised in a timely manner (Hoogervorst, 2012, Ramanna and Watts, 2012; Ji, 2013; ASBJ et al., 2014; IFRS Foundation, 2014; KPMG, 2014; Filip et al., 2015). Second, absence the amortisation of goodwill, the late recognition of the impairment losses temporarily overstates goodwill presented on the financial statements (EFRAG, 2016; Li and Sloan, 2017). From the standard-setter point of views, concerns on the late recognition of goodwill impairment losses were highlighted by the Chairman of the IASB, Mr. Hans Hoogervorst who commented that the recognition of goodwill impairment losses often lagged behind share performance (Hoogervorst, 2012). Consequently, decisions made by the IASB in conducting a Post-implementation Review of IFRS 3 in 2013 and in adding two issues on goodwill (i.e., effectiveness and complexity of testing goodwill for impairment, and subsequent accounting for goodwill) as their higher-priority research project in February 2015 (IFRS Foundation, 2015; Schatt, 2016: 2) represent initiatives to address the issue.

Regulatory bodies, audit firms and reporting advisory groups in various countries also seem to echo similar concerns on goodwill impairment losses that were recognised quite late (ESMA, 2013; ASBJ et al., 2014; FRC, 2014; KPMG, 2014; EFRAG, 2016). For example, the European Securities and Markets Authority (ESMA) examined accounting and disclosures practices related to impairment tests of goodwill among 235 largest European listed firms that have significant goodwill in their financial statements for 2011 (ESMA, 2013). Their findings showed a relatively limited amount of goodwill impairment losses reported by these firms despite the financial crisis that occurred in 2008/2009. These findings led ESMA (2013) to question whether firms' recognition of goodwill impairment losses reflect the significant declined in their market capitalisation and the worsened economic conditions faced by these firms. Similarly, in 2012 members of the Accounting Standards Board of Japan (ASBJ), the European Financial Reporting Advisory Group (EFRAG) and the Italian standard-setter (the Organismo Italiano di Contabilita - OIC) set up a research group to undertake a survey on an impairment-only approach (ASBJ et al., 2014). They reported that many respondents questioned whether impairment losses of goodwill were recognised on a timely basis (ASBJ et al., 2014).

Prompted by the Post-implementation Review of IFRS 3, KPMG International Standards Group undertook interviews with stakeholders in various regions worldwide (KPMG, 2014). Their findings showed that most respondents agreed that goodwill impairment charges lagged behind actual impairment losses (KPMG, 2014). 
In addition, EFRAG (2016) examined accounting practices related to goodwill among 328 European listed firms from 2005-2014. They found inconclusive evidence to support the effectiveness of an impairment model in generating reliable outcomes (EFRAG, 2016).

From an academic perspective, a number of studies have been carried out to identify the likelihood that firms delayed recognising goodwill impairment losses (e.g., Ramanna and Watts, 2012; Filip et al., 2015; Andre et al., 2016; Li and Sloan, 2017). For example, Ramanna and Watts (2012) examined non-impairment of goodwill among 124 US listed firms from 2003-2006 that have market indications that their goodwill may be impaired. Their investigation revealed that $69 \%$ of the US listed firms they examined do not report goodwill impairment losses. Instead of focusing on a specific country, Andre et al. (2016) compared the frequency and magnitude of goodwill impairment losses reported by European listed firms with that of the US listed firms. Using 35,063 observations, their findings revealed that during the financial crisis, the European listed firms reported significantly smaller proportion of goodwill impairment losses relative to goodwill balance (6\% in 2008 and $7 \%$ in 2009) than those of the US listed firms (63\% in 2008 and $40 \%$ in 2009). Incidences of firms not taking goodwill write-offs are also found in South East Asian countries, such as Malaysia and Singapore (e.g., Abdul Majid, 2015 and 2017). For example, Abdul Majid (2015) documented a large frequency of listed firms in Malaysia reported zero goodwill impairment in 2008 to 2010 (76\% in 2008, 81\% in 2009 and $77 \%$ in 2010) despite the country experiencing the full impact of the financial crisis in the first quarter of 2009.

\subsection{Causes of the Debates}

Shortcomings in the application of an impairment model often are identified as a primary cause for the late recognition of goodwill impairment losses (Cairns, 2015; Johansson et al., 2016). Many argued that an impairment model fails to separate out the subsequent internally generated goodwill, which may cause firms not to recognise their goodwill impairment losses on a timely basis (IASB, 2006; KPMG, 2014; Cairns, 2015; Johansson et al., 2016; IFRS Foundation, 2017a). Moreover, with an abolition of an amortisation of goodwill, an impairment model lacks rigorousness (IASB, 2006a; IASB, 2006b). As a result, an impairment model has been criticised for failing to effectively capture goodwill impairment losses in an appropriate amount or at an appropriate time, also known as "too little, too late" issue (ASBJ et al., 2014; ASBJ, 2017; EFRAG, 2017; IFRS Foundation 2017b).

Another shortcoming in the application of an impairment model, as argued by prior studies, is managerial discretions associated with the impairment testing of goodwill (Ramanna, 2008; Chambers and Finger, 2011; Ramanna and Watts, 2012; Hartwig, 2015). Managerial discretions that are frequently discussed in the literature include identification of cash-generating units to which goodwill is allocated (Ernst and Young, 2007; AbuGhazaleh et al. , 2011; Abdul Majid, 2013), estimations of fair value of the reporting units containing goodwill (Ramanna, 2008; Chambers and Finger, 2011; Ramanna and Watts, 2012; Li and Sloan, 2017) and determination of discount rates in the estimation of value in use (AbuGhazaleh et al., 2011; ASBJ et al. 2014; IFRS Foundation, 2015). ASBJ et al. (2014) explain that even though auditors may challenge the estimations and judgements made by management, they find it hard to refute these discretions decisively. Li and Sloan (2017) illustrate that challenges in verifying fair value estimates contribute to the relatively more inflated goodwill balances and less timely recognition of goodwill impairment losses of the 19,290 observations of US listed firms they examined during the impairment-only regime.

\subsection{Proposed Solutions Offered by Stakeholders}

Various solutions have been proposed to address the shortcomings in the application of an impairment model. Two main models that are commonly discussed are the amortisation of goodwill that had been abolished by the IASB, and the existing impairment-only approach. The amortisation of goodwill model required firms to reduce the amount of goodwill systematically on an annual basis over the useful life of the goodwill. Hence, management has to estimate the useful life of the goodwill. On the other hand, the existing impairment model requires firms to perform an annual impairment review of goodwill by comparing the recoverable amount of cash-generating unit(s) (CGU) containing goodwill with the carrying amount of the unit. If the recoverable amount is lower than the carrying amount, firms are required to reduce the amount of goodwill through an impairment loss. Hence, under the impairment model, firms are not required to reduce their goodwill balance systematically on an annual basis. In addition, the impairment model necessitates management to exercise judgement in estimating the recoverable amount of the CGU(s).

Advocates of an amortisation-based model call for a reintroduction of an amortisation of goodwill, arguing that the periodic amortisation enables consumption of acquired goodwill to be recognised in profit or loss rather than being shielded by internally generated goodwill under the impairment model (ASBJ et al. 2014; KPMG, 2014). 
Moreover, an amortisation-based model requires less judgements and estimations than an impairment model, which may enhance the level of reliability and verifiability in accounting treatments for goodwill (ASBJ et al. 2014; KPMG, 2014).

Proponents of an impairment-only approach maintain that although an impairment model has its limitations, in general, it generates more relevant information to the capital market than an amortisation-based model (KPMG, 2014). In addition, they emphasise that compared to an amortisation-based model, an impairment model provides information that is helpful to users in assessing management's stewardship of the firms' assets and the performance of an investment (FRC, 2014; KPMG, 2014). FRC (2014) conducted an outreach meeting of the Post-implementation Review of IFRS 3 that was attended by 40 respondents. They reported that although there were mixed views on the usefulness of information generated from an impairment-only model, the majority of the respondents regarded the impairment-only model to be an appropriate approach (FRC, 2014).

Apart from amortisation vs. impairment debates, there are also those who suggested for a hybrid model that includes periodic amortisation and an indicator-based impairment testing of goodwill, or those who argued that goodwill should be written off immediately (KPMG, 2014; Boyle et al., 2015). Looking back in history of an accounting for goodwill, one would realise that these proposed solutions are not novel as they had been stipulated by former accounting standards on goodwill and had been practiced by many firms prior to the implementation of IFRS 3 (Johansson et al., 2016).

Despite the shortcomings in the application of an impairment model, what is interesting from reviewing the empirical studies on an impairment-only approach is that with the implementation of an impairment-only approach, listed firms worldwide have improved their disclosure on goodwill and its impairment test over time. For example, in Malaysia, Carlin et al. (2009) reported a 56\% compliance with the disclosure requirements related to an impairment test of goodwill in 2006, the initial year of the IFRS 3 implementation. Two years afterward, Abdullah et al. (2015) reported that the level of compliance with the disclosure requirements of MFRS 3 (IFRS 3) and MFRS 136 (IAS 36 Impairment of Assets) in Malaysia increased to more than 70\% (mean 77\% for MFRS 3 and mean 72\% for MFRS 136) for 121 listed firms they examined for the financial year ended 31 December 2008.

The improvement in firms' disclosures of goodwill and its impairment test is also evidenced in other countries. For example, an investigation of goodwill disclosure practices among 287 Australian listed firms from 2005-2010 by Guthrie and Pang (2013) showed that the level of compliance with the disclosure requirements to allocate goodwill to cash-generating units increased from $61 \%$ in 2005 to $80 \%$ in 2010. Likewise, the examination of the disclosure requirements of paragraph 134 of IAS 36 among 472 Dutch and Swedish listed firms for 2005 and 2008 by Hartwig (2015) showed an improvement in the compliance levels over time from an average of $52.7 \%$ in 2005 to $61.9 \%$ in 2008 .

Even though, prior studies reported that full compliance with the disclosure requirements of goodwill and its impairment test is not yet achievable (Glaum et al., 2013; Abdullah et al., 2015) and these disclosures lack entity-specific (FRC, 2008; ESMA, 2013; KPMG, 2014), users of annual reports and especially analysts and bank officers express high demand for the disclosure of critical accounting estimates and impairment tests of goodwill (Johansen and Plenaborg, 2013; KPMG, 2014). KPMG (2014) elaborated that some analysts seek disclosures of goodwill impairment test to aid them in their valuation model. In addition, Baboukardos and Rimmel (2014) analysis of 76 Greek listed firms found goodwill to be value relevant, especially for firms with high level of disclosure of IFRS 3 and IAS 36.

\section{Conclusion and Suggestions for Future Research Opportunities}

This paper presents a selected review of contemporary issues surrounding an impairment-only approach to accounting for acquired goodwill and addresses the question of whether an impairment-only approach has resulted in an improvement in an accounting for goodwill. The selected review demonstrates that even though an impairment-only approach has posed implementation, auditing and enforcement challenges, it has also encouraged standard-setters, regulators and firms worldwide to make concerted efforts in bringing in more clarity to the valuation of goodwill and its impairment test.

This paper has three specific recommendations for future research. First, research results have highlighted the shortcoming in the application of an impairment model. Few studies have attempted to address this shortcoming by seeking to understand how firms implement impairment test through survey questionnaires (e.g., Petersen and Plenborg, 2010; Mazzi et al., 2016). To provide greater insight into this shortcoming in order to offer relevant and practical solutions, it is recommended for future works to focus on conducting interviews with key personnel in-charged with the impairment test. 
Second, the review of the empirical studies has demonstrated that improvements have been made in an accounting for goodwill and its impairment test through firms' disclosures (Guthrie and Pang, 2013; Hartwig, 2015) though these improvements, at present, are below our expectation. Thus, there is a need for more research on firms' disclosures focusing on how firms conduct their impairment review and how firms disclose the judgement involved in the impairment tests, so as to identify best practices, which then could be mimicked by other firms.

Third, d'Arcy and Tarca (2018), in their review of research on IFRS goodwill accounting, highlight the need for researchers to explore new data source. In this paper, it is suggested that one possible source that worth the investigation is the Key Audit Matters in the independent auditor's report. Analysing issues related to goodwill impairment highlighted by independent auditors in the Key Audit Matters help provide insight on how auditors addressed the issue, which could generate inputs to further improve the disclosure requirements on goodwill impairment.

In sum, this paper suggests that in the case of an impairment-only approach to accounting for acquired goodwill, the way forward is for standard-setters, regulators, researchers and various stakeholders to focus more on improving the impairment model and for firms to further enhance the quality of existing disclosure of goodwill impairment and its test.

\section{Acknowledgements}

Financial support from the Ministry of Higher Education in Malaysia via the Universiti Utara Malaysia under the FRGS research grant (Grant number 13591) is gratefully acknowledged.

\section{References}

Abdul, M. J. (2013). Accounting choices relating to goodwill impairment: Evidence from Malaysia (Unpublished Ph.D. thesis). University of Glasgow, Scotland, United Kingdom.

Abdul, M. J. (2015). Reporting incentives, ownership concentration by the largest outside shareholder, and reported goodwill impairment losses. Journal of Contemporary Accounting \& Economics, 11, 199-214. https://doi.org/10.1016/j.jcae.2015.07.002

Abdul, M. J. (2017). Audit committee independence and a contracting perspective on goodwill impairment: Singaporean evidence. Business: Theory and Practice, 18, 128-135. https://doi.org/10.3846/btp.2017.013

Abdullah, M., Evans, L., Fraser, I., \& Tsalavoutas, I. (2015). IFRS mandatory disclosures in Malaysia: the influence of family control and the value (ir)relevance of compliance levels. Accounting Forum. https://doi.org/10.1016/j.accfor.2015.05.003

AbuGhazaleh, N. M, Al-Hares, O. M., \& Roberts, C. (2011). Accounting discretion in goodwill impairments: UK evidence. Journal of International Financial Management \& Accounting, 22(3), 165-204. https://doi.org/10.1111/j.1467-646X.2011.01049.x

Accounting Standards Board of Japan (ASBJ), European Financial Reporting Advisory Group (EFRAG) and Organismo Italiano di Contabilita (OIC) (ASBJ et al.). (2014). Should goodwill still not be amortised?. Retrieved from http://www.efrag.org/files/Goodwill\%20Impairment\%20and\%20Amortisation/140725_Should_goodwill_st ill_not_be_amortised_Research_Group_paper.pdf

Accounting Standards Board of Japan (ASBJ). (2017). Possible Approach for Addressing the "Too Little, Too Late" Issue, Accounting Standards Advisory Forum June 2017. ASAF Agenda Paper 3. Retrieved from http://www.ifrs.org/-/media/feature/meetings/2017/july/asaf/goodwill-and-impairment/asaf-03-possible-app roach-for-addressing-too-little-too-late-issue.pdf

Andre, P., Filip, A., \& Paugam, L. (2016). Examining the patterns of goodwill impairments in Europe and the US. Accounting in Europe. https://doi.org/10.1080/17449480.2016.1260748

Baboukardos, D., \& Rimmel, G. (2014). Goodwill under IFRS: Relevance and disclosures in an unfavorable environment. Accounting Forum, 38, 1-17. https://doi.org/10.1016/j.accfor.2013.11.001

Boyle, D. M., Carpenter, B. W., \& Mahoney, D. P. (2015). The continuing saga of goodwill accounting. Management Accounting Quarterly Fall 2015, 17(1), 1-8. Retrieved from file:///C:/Users/User/Downloads/maq_fall_2015_boyle\%20(1).pdf

Cairns, D. (2015). Financial reporting in Europe: Future challenges. Accounting in Europe, 12(2), 187-196. https://doi.org/10.1080/17449480.2015.1114181 
Carlin, T. M., Finch, N., \& Laili, N. H. (2009). Investigating audit quality among Big 4 Malaysian firms. Asian Review of Accounting, 17(2), 96-114. https://doi.org/10.1108/13217340910975251

Central Bank of Malaysia. (2009). Annual report of Bank Negara Malaysia. Economic developments in 2009. Retrieved from https://www.bnm.gov.my/files/publication/ar/en/2009/cp01.pdf

Chambers, D., \& Finger, C. (2011). Goodwill non-impairments. Evidence from recent research and suggestions for auditors. The CPA Journal, February 2011, 38-41.

d'Arcy, A., \& Tarca, A. (2018). Reviewing IFRS goodwill accounting research: Implementation effects and cross-country differences. The International Journal of Accounting, 53(3), 203-226. https://doi.org/10.1016/j.intacc.2018.07.004

Deller, A. (2017). The IASB has entered the lion's den with papers on goodwill and intangibles acquired in a business combination. International edition of Accounting and Business magazine. Retrieved from http://www.accaglobal.com/my/en/member/discover/cpd-articles/corporate-reporting/goodwill-recognition1 7.html

Ernst \& Young. (2007). IAS 36 Impairment testing: Practical issues. Retrieved on October 15, 2009 from http://www.ey.com/BE/en/Issues/IFRS/IFRS

European Financial Reporting Advisory Group (EFRAG). (2016). What do we really know about goodwill and impairment? A quantitative study. Retrieved from

http://www.efrag.org/Assets/Download?assetUrl=/sites/webpublishing/SiteAssets/EFRAG\%2520Quantitati ve\%2520Study\%2520Goodwill\%25202016.pdf\&AspxAutoDetectCookieSupport=1

European Financial Reporting Advisory Group (EFRAG). (2017). Goodwill and impairment - Issues paper. Retrieved from https://www.efrag.org/Assets/Download?assetUrl=\%2Fsites\%2Fwebpublishing\%2FMeeting\%20Document s\%2F1609261453414415\%2F13-01\%20Issues\%20paper\%20on\%20Goodwill\%20and\%20Impairment\%20\%20EFRAG\%20TEG\%20CFSS\%2017-06-28.pdf\&AspxAutoDetectCookieSupport=1

European Securities and Markets Authority (ESMA). (2013). European enforcers review of impairment of goodwill and other intangible assets in the IFRS financial statements. Retrieved from https://www.esma.europa.eu/document/european-enforcers-review-impairment-goodwill-and-other-intangib le-assets-in-ifrs-financial

Filip, A., Jeanjean, T., \& Paugam, L. (2015). Using real activities to avoid goodwill impairment losses: Evidence and effect on future performance. Journal of Business Finance \& Accounting, 42(3) \& (4), 515-554, April/May 2015, 0306-686X. https://doi.org/10.1111/jbfa.12107

Financial Reporting Council (FRC). (2008). Review of goodwill impairment disclosures. Retrieved from https://www.frc.org.uk/getattachment/3a4d7fd1-44ef-45bd-8bfb-eac6eb4a911c/;.aspx

Financial Reporting Council (FRC). (2014). Post-implementation Review: IFRS 3 Business Combinations. Retrieved from https://www.frc.org.uk/getattachment/cb12e9d5-3272-47bb-82bd-2cc7378ff7c1/20140530-FRC-response-t o-IFRS-3-RFI_Final.pdf

Giner, B., \& Pardo, F. (2014). How ethical are managers' goodwill impairment decisions in Spanish-listed firms? Journal of Business Ethics, 132(1), 21-40. https://doi.org/10.1007/s10551-014-2303-8

Glaum, M., \& Wyrwa, S. M. A. (2009). Making acquisitions transparent. Goodwill accounting in times of crisis', PwC. Retrieved from www.pwc.de

Glaum, M., Schmidt, P., Street, D. L., \& Vogel, S. (2013). Compliance with IFRS 3- and IAS 36-required disclosures across 17 European countries: company- and country-level determinants. Accounting and Business Research, 43(3), 163-204. https://doi.org/10.1080/00014788.2012.711131

Gunn, J. L., Khurana, I. K., \& Stein, S. E. (2017). Determinants and consequences of timely asset impairments during the financial crisis. Journal of Business Finance \& Accounting, 45(1-2), January - February 2018, 3-39.

Guthrie, J., \& Pang, T. T. (2013). Disclosure of goodwill impairment under AASB 136 from 2005-2010. Australian Accounting Review, 66(23)(3), 216-231. https://doi.org/10.1111/j.1835-2561.2013.00204.x

Hartwig, F. (2015). Swedish and Dutch listed companies' compliance with IAS 36 paragraph 134. International Journal of Disclosure and Governance, 12(1), 78-105. https://doi.org/10.1057/jdg.2013.33 
Hoogervorst, H. (2012). The imprecise world of accounting. Speech delivered at the International Association for Accounting Education \& Research (IAAER) conference. Retrieved from https://www.iasplus.com/en/news/2012/june/speech-by-hans-hoogervorst-on-the-imprecise-world-of-accou nting

IASB. (2006a). IFRS 3 Business Combinations, In International Financial Reporting Standards as at 1 January 2006 (pp. 273-394), International Accounting Standards Board (IASB), London: IASCF Publications Department.

IASB. (2006b). IAS 36 Impairment of Assets, In International Financial Reporting Standards as at 1 January 2006 (pp. 1449-1595), International Accounting Standards Board (IASB), London: IASCF Publications Department.

IASplus. (Undated). Post-implementation review - IFRS 3. Retrieved from https://www.iasplus.com/en/projects/pir/ifrs-3-pir

IFRS Foundation. (2014). Post-implementation Review: IFRS 3 Business Combinations. Request for information. Retrieved from

http://archive.ifrs.org/Current-Projects/IASB-Projects/PIR/PIR-IFRS-3/Request-for-Information-January-20 14/Documents/RfI_PIR_IFRS3-Business-Combinations.pdf

IFRS Foundation. (2015). Post-implementation Review of IFRS 3 business combinations. Report and Feedback Statement. Retrieved from http://www.ifrs.org/-/media/project/pir-ifrs-3/published-documents/pir-ifrs-3-report-feedback-statement.pdf

IFRS Foundation. (2017a). Improving effectiveness of goodwill impairment testing model. Accounting Standards Advisory Forum September 2017, ASAF Agenda Paper 5B. Retrieved from http://www.ifrs.org/-/media/feature/meetings/2017/september/asaf/goodwill-and-impairment/ap5b-improvin -effectiveness-of-impairment-test.pdf

IFRS Foundation. (2017b). Goodwill and impairment research project. IASB Meeting October 2017, IASB Agenda ref 18A. Retrieved from http://www.ifrs.org/-/media/feature/meetings/2017/october/iasb/goodwill-and-impairment/ap18-cover-paper .pdf

Jenkins, P. (2017). A decade on from the financial crisis, what have we learnt. Financial Times. Retrieved from https://www.ft.com/content/543359aa-8d0d-11e7-a352-e46f43c5825d

Ji, K. (2013). Better late than never, the timing of goodwill impairment testing in Australia. Australian Accounting Review, 67(23)(4), 369-379. https://doi.org/10.1111/auar.12036

Johansen, T. R., \& Plenborg, T. (2013). Prioritising disclosures in the annual report. Accounting and Business Research, 43(6), 605-635. https://doi.org/10.1080/00014788.2013.827105

Johansson, S. E., Hjelstrom, T., \& Hellman, N. (2016). Accounting for goodwill under IFRS: A critical analysis. Journal of International Accounting, Auditing and Taxation, 27, 13-25. https://doi.org/10.1016/j.intaccaudtax.2016.07.001

KPMG. (2014). Who cares about goodwill impairment? A collection of stakeholder views. Retrieved from https://assets.kpmg.com/content/dam/kpmg/pdf/2014/04/impairment-qa.pdf

Laux, C., \& Leuz, C. (2010). Did fair-value accounting contribute to the financial crisis? Journal of Economic Perspectives, 24(1), 93-118. https://doi.org/10.1257/jep.24.1.93

Li, K. K., \& Sloan, R. G. (2017). Has goodwill accounting gone bad?. Review of Accounting Studies. Published online on 6 May 2017. https://doi.org/10.1007/s11142-017-9401-7

Mazzi, F., Liberatore, G., \& Tsalavoutas, I. (2016). Insights on CFOs' perceptions about impairment testing under IAS 36. Accounting in Europe, 13(3), 353-379. https://doi.org/10.1080/17449480.2016.1244341

Petersen, C., \& Plenborg, T. (2010). How do firms implement impairment tests of goodwill? Abacus, 46(4), 419-446. https://doi.org/10.1111/j.1467-6281.2010.00326.x

Ramanna, K. (2008). The implications of unverifiable fair-value accounting: Evidence from the political economy of goodwill accounting. Journal of Accounting and Economics, 45, 253-281. https://doi.org/10.1016/j.jacceco.2007.11.006

Ramanna, K., \& Watts, R. L. (2012). Evidence on the use of unverifiable estimates in required goodwill 
impairment. Review of Accounting Studies, 17, 749-780. https://doi.org/10.1007/s11142-012-9188-5

Schatt, A., Doukakis, L., Bessieux-Ollier, C., \& Walliser, E. (2016). Do Goodwill Impairments by European Firms Provide Useful Information to Investors? Accounting in Europe, 1-21.

Sussholz, E. (2009). Speech by SEC staff: Remarks before the 2009 AICPA national conference on current SEC and PCAOB developments. Retrieved from https://www.sec.gov/news/speech/2009/spch120709es.htm

\section{Copyrights}

Copyright for this article is retained by the author(s), with first publication rights granted to the journal.

This is an open-access article distributed under the terms and conditions of the Creative Commons Attribution license (http://creativecommons.org/licenses/by/4.0/). 